\title{
FILSAFAT DAN AGAMA; SEBUAH KAJIAN KOMPROMIS-ANALITIS
}

\author{
Abd. Aziz*
}

Abstract: According to Al-Farabi, philosophy is a knowledge of materiel and a way to investigate the real essence of universe. Whereas religion, according to J.G. Frazer, is a devotion to God who puts in order universe movement. When philosophy and religion are faced one and other, both of them are looked like something incompatible, even in factually they are completing each other. In order to have a better religion, someone needs to have his rationality in the way of understanding religion. And also, to control philosophy which is based on rationality, philosophy needs a religion guidance. Many people perceive that philosophy could not be in harmony with religion, since philosophy anchored its idea to the rationalistic-empiricism basics and religion based its idea to the transcendentally dalîlof Supra Causa. Therefore, Emile Durkheim said, religion was a mystical paradigm where rationality could not get into. So did Auguste Comte, he said people need a religion only when he had no ability to develop his rationality. Even contrary, does religion order people to always "think"? and also, if people have a great rationality, people will realize that to achieve the balance of using, his rationality must be restrained and religion is the best restrainer, this was what al-Ghazali stated. So, actually, philosophy can strengthen the religious soul of people, since philosophy can interpret the universality of the dalill, philosophy can systemize and definite religious order, philosophy can solve the new problem which is not stated in the dalill, and of course philosophy also can be a tool to criticize a variety of unlogical religious ideology.

Keywords: philosophy, and religion

\footnotetext{
* Dosen tetap Institut Ilmu Keislaman Zainul Hasan Genggong Kraksaan
} 


\section{A. Pendahuluan}

Diskursus tentang filsafat dan agama secara sekilas, oleh kebanyakan orang, selalu diartikan sebagai sesuatu yang berlawanan, filsafat di kutub Utara dan agama di kutub Selatan. Filsafat dalam cara kerjanya berpangkal dari akal, sedangkan agama berpangkal dari wahyu. Oleh sebab itu, filsafat identik dengan kegiatan berpikir secara radikal, dan agama banyak terkait dengan "pengalaman." Filsafat mebahas sesuatu dalam rangka melihat kebenaran yang diukur, apakah sesuatu itu logis atau tidak. Dalam agama, kajian tidak selalu diukur dari segi thinkable atau un-thinkablenya, karena agama dipandang sebagi sesuatu yang berasal dari sang supra logic. ${ }^{1}$

Perbedaan tersebut menimbulkan konflik berkepanjangan antara orang yang cenderung berpikir filosofis dengan orang yang berpikir agamis, padahal filsafat dan agama mempunyai fungsi yang sama kuat untuk kemajuan, keduanya tidak bisa dipisahkan dari kehidupan manusia.

Dalam hipotesa sederhana dipahami bahwa antara agama dan filsafat terdapat perbedaan. Perbedaan antara filsafat dan agama bukan terletak pada bidangnya (objek materiil), tetapi terletak pada cara menyelidiki bidang itu sendiri(objek formil), demikian menurut H. Rasyidi. ${ }^{2}$ Filsafat adalah berfikir, sedangkan agama adalah mengabdikan diri, agama banyak berhubungan dengan hati, sedangkan filsafat banyak berkaitan dengan pemikiran. Williem Temple, seperti yang dikutip Rasyidi, mengatakan bahwa filsafat menuntut pengetahuan untuk memahami, sedangkan agama menuntut pengetahuan untuk beribadah atau mengabdi. ${ }^{3}$ Pokok agama bukan pengetahuan tentang Tuhan, tetapi yang penting adalah hubungan manusia dengan Tuhan. ${ }^{4}$

Apa sebenarnya filsafat dan agama itu? Apakah ada peran yang saling melengkapi di antara keduanya? Benarkah filsafat tidak dapat dipadukan dengan agama?

1 Umar Faruq Thohir, "Keseimbangan Doa dan Usaha; Paradigma Baru Efektifitas Manajemen Kehidupan,” dalam Lukas Awi Tristanto (ed.), Inspirasi: Memaknai kembali Arti Devosi (Semarang: Suryandaru Utama, 2011), hlm. 14-15.

2 Rasyidi, Filsafat Agama (Jakarta: Bulan Bintang, 1965), hlm. 3.

3 Ibid.,hlm.3-4; Syed Muhammad Al-Naquib Al-Attas, Islam dan Sekularisme, alih bahasa Karsidjo Djojosuwarno (Bandung: Penerbit Pustaka, 1981), hlm. 17-24.

4 Agama berawal dari keyakinan, sedangkan filsafat beranjak dari mempertanyakan hakikat sesuatu (keraguan). Ahmad Mahmud Subhi, Dirâsât Falsafiyyah fi 'Ilm al-Kalâm (ttp.: Dâr al-Kutub al-Jami'iyyah, 1969), hlm. 4. 
Melalui metode komparasi, setelah melakukan analisis, penyusun menemukan bahwa sejatinya filsafat dan agama dapat bersatu-padu, filsafat dapat dijadikan sebagai objek formil (pisau analisis) ketika melakukan kajian mendalam, sistematis, dan komprehensif terhadap agama. Agama adalah norma-universal yang berisi tentang ajaran-ajaran yang harus selalu dikaji, bahkan dengan filsafat yang sangat rasional sekalipun. Hal ini harus dilakukan disamping agar kajian agama tidak mengalami kejumudan, agama juga memerintahkan penganutnya untuk melakukan pemahaman terhadap agama, dan filsafat adalah salah satu metodenya.

\section{B. Pengertian Filsafat}

Salah satu adadium dunia penelitian dan keilmuan adalah bahwa penemuan konsep tentang sesuatu berawal dari pengetahuan tentang satuan-satuan. Setiap satuan yang ditemukan itu dipilah-pilah, dikelompokkan berdasarkan persamaan, perbedaan, ciri-ciri tertentu dan sebagainya. Berdasarkan penemuan yang telah diverivikasi itulah orang merumuskan definisi tentang sesuatu itu. ${ }^{5}$ Dalam sejarah perkembangan pemikirian manusia, filsafat juga bukan diawali dari definisi, tetapi diawali dengan kegiatan berfikir tentang segala sesuatu secara mendalam. ${ }^{6}$ Pada awalnya, definisi filsafat sangatlah sederhana dan kemudian disempurnakan oleh orang yang datang berikutnya.

Secara etymology, filsafat berasal dari kata Arab falsafah, yang berasal dari bahasa Yunani philosophia, dari akar kata philos yang artinya cinta, dan sophia yang artinya pengetahuan, kebijakan. Jadi philosophia berarti cinta pada kebijaksanaanatau cinta pada kebenaran. Orang yang cinta

5 Akh. Minhaji menyebut ini sebagai theory, yaitu sebuah pernyataan atas kesimpulan tentang hasil penelitian yang diambil dari sesuatu yang nyata dan teruji (empiristic experimental). LihatAkh. Minhaji, Strategies for Social Research: The Methodological Imagination in Islamic Studies (Yogyakarta: Suka-Press, 2009), hlm. 85-89.

6 Oleh karena itulah, dengan mengikuti alur pemikiran ini, Muhammad Hatta dan Langeveld, sebagaimana dikutip Ahmad Tafsir mengatakan "lebih baik pengertian filsafat itu tidak dibicarakan lebih dahulu. Jika orang telah banyak membaca filsafat ia akan mengerti sendiri apa filsafat itu." Lihat Ahmad Tafsir, Filsafat Umum, Akal dan Hati sejak Thales sampai James (Bandung: Rosdakarya, 1994), hlm. 8. 
kepada pengetahuan disebut philosopher, dalam bahasa Arabnya failasîf. ${ }^{7}$ Pecinta pengetahuan ialah orang yang menjadikan pengetahuan sebagai tujuan hidupnya.

Berfilsafat artinya berpikir. Namun tidak semua berpikir berarti berfilsafat. Semua manusia berakal pasti berpikir, namun tidak semua manusia berpikir adalah filsuf.

Menurut Plato, Filsafat adalah pengetahuan tentang segala yang ada (ilmu pengetahuan yang berminat mencapai ilmu pengetahuan yang asli). ${ }^{8}$

Lebih jelas lagi, Aristoteles mendefinisikan filsafat sebagai ilmu pengetahuan yang meliputi kebenaran, yang di dalamnya terkandung ilmuilmu metafisika, logika, retorika, etika, ekonomi, politik dan estetika (filsafat menyelidiki sebab dan asas segala benda). ${ }^{9}$ Dalam pengertian yang sama, Thomas Hobes (1588-1679 M) salah seorang filosof Inggris mengemukakan filsafat ialah ilmu pengetahuan yang menerangkan hubungan hasil dan sebab, atau sebab dan hasilnya dan oleh karena itu terjadi perubahan. ${ }^{10}$

Sedangkan menurut Marcus Tulius Cicero, filsafat adalah pengetahuan terluhur dan keinginan untuk mendapatkannya. ${ }^{11} \mathrm{R}$. Berling mengatakan

${ }^{7}$ H. A. mustofa, Filsafat Islam untuk Fakultas Tarbiyah, Syari'ah, Dakwah, Adab, dan Ushuluddin, Komponen MKDK (Bandung: Pustaka Setia, 2004), hlm.9.

${ }^{8}$ Ibid.,hlm. 10.

9 Ibid., juga dapat dilihat di Hamzah Ya'qub, Filsafat Agama (Jakarta: Pedoman Ilmu Jaya, 1991), hlm. 3. Kattsoff mengemukakan filsafat, ialah ilmu penge-tahuan yang dengan cahaya kodrati akal budi mencari sebab-sebab yang pertama atau azas-azas yang tertinggi segala sesuatu. Filsafat dengan kata lain merupakan ilmu pengeahuan tentang hal-hal pada sebab-sebabnya yang pertama termasuk dalam ketertiban alam. Lihat Louis O. Kattsoff, Pengantar Filsafat, terjemahan dari Element of Philosophy, oleh Soejono Soemargono, (Yogyakarta: Tiara Wacana, 1992), hlm. 67.

${ }^{10} \mathrm{Ibid}$., Alfred Ayer mengatakan filsafat adalah pencarian akan jawaban atas sejumlah pertanyaan yang sudah ada semenjak zaman Yunani dalam hal-hal pokok. Pertanyaan-pertanyaan mengenai apa yang dapat diketahui dan bagaimana mengetahuinya, hal-hal apa yang ada dan bagaimana hubungannya satu sama lain. Selanjutnya mempermasalahkan apa-apa yang dapat diterima, mencari ukuranukuran dan menguji nilai-nilainya apakah asumsi dari pemikiran itu dan selanjutnya memeriksa apakah hal itu berlaku. Lihat Gerard Beekman, Filsafat para Filosof Berfilsafat, diterjemahkan oleh R. A. Rifai dari Filosofie, Filosofen, dan Filosoferen (Jakarta: Erlangga, 1984), hlm. 14.

${ }^{11}$ Marcus Tulius Cicero, selain sebagai filsuf, dia juga seorang politikus dan ahli pidato Romawi. Cicero hidup sekitar 106 SM sampai 43 SM. Lihat H. A. Mustofa, Filsafat Islam, hlm.10; jugadapatdilihat di Hamzah Ya'qub, Filsafat Agama, hlm. 3. 
filsafat adalah pemikiran-pemikiran yang bebas diilhami oleh rasio mengenai segala sesuatu yang timbul dari pengalaman-pengalaman. ${ }^{12}$

Menurut Al-Farabi, filsafat adalah ilmu pengetahuan tentang alam maujud dan bertujuan menyelidiki hakikat yang sebenarnya. ${ }^{13}$

Dengan lebih jelas, Immanuel Kant (1724-1804 M) salah seorang filosof Jerman mengatakan filsafat adalah ilmu pokok dan pangkal segala pengetahuan yang mencakup tiga persoalan: yaitu Apa yang dapat diketahui?, Jawabnya: Metafisika. Apa yang seharusnya diketahui? Jawabnya: etika. Sampai di mana harapan kita? Jawabnya: Agama. Apa manusia itu? Jawabnya Antropologi. ${ }^{14}$

H. Hasbullah Bakry merumuskan bahwa filsafat adalah ilmu yang menyelidiki segala sesuatu dengan mendalam mengenai Ketuhanan, alam semesta, dan manusia sehingga menghasilkan pengetahuan bagaimana hakikatnya. ${ }^{15}$

Dari beberapa terminology tersebut, penyusun menyimpulkan bahwa filsafat adalah daya upaya manusia dengan akal budinya untuk memahami secara radikal, sistematis, rasional, koheren, komprehensif tentang hakikat Tuhan, hakikat alam semesta, hakikat manusia dan sikapnya. ${ }^{16}$

\section{Pengertian Agama}

Kata "agama" berasal dari bahasa Sankskrit " $a$ " yang berarti tidak dan "gam" yang berarti pergi, tetap di tempat, diwarisi turun temurun dalam kehidupan manusia. ${ }^{17}$ Ternyata agama, bagi orang-orang tertentu, memang mempunyai sifat seperti itu, selain sebagai pola hidup manusia. Dick Hartoko menyebut agama itu dengan religi, yaitu ilmu yang meneliti hubungan antara manusia dengan "Yang Kudus" dan hubungan

${ }^{12}$ Gerard Beekman, Filsafat, hlm. 14.

${ }^{13}$ H. A. mustofa, Filsafat Islam, hlm. 10.

${ }^{14}$ LihatJujun S Suriasumantri,FilsafatIlmu, SebuabPengantarPopuler (Jakarta: SinarHarapan, 1995), hlm.25; Ahmad Tafsir, FilsafatUmum, hlm.9; jugadapatdilihat di H. A. mustofa, Filsafat Islam, hlm. 10.

${ }^{15} \mathrm{Ibid}$., hlm.10-11.

${ }^{16}$ H.A. Dardiri, Humaniora, Filsafat dan Logika (Jakarta: Rajawali Press, 1986), hlm. 10-11.

${ }^{17}$ Harun Nasution, Islam Ditinjau dari Berbagai Aspeknya, cet. ke-1 (Jakarta: Universitas Indonesia Press, 1979), hlm. 9. juga dapat dilihat di Amsal Bakhtiar, Filsafat Agama I (Jakarta: Logos Wacana Ilmu, 1997), hlm. 10 
itu direalisasikan dalam ibadat-ibadat. ${ }^{18}$ Kata religi berasal dari bahasa Latin relegere yang berarti mengumpulkan, membaca. Agama memang merupakan kumpulan cara-cara mengabdi kepada Tuhan dan semua cara itu terkumpul dalam kitab suci yang harus dibaca. Di sisi lain kata religi berasal dari religare yang berartimengikat. Ajaran-ajaran agama memang mem-punyai sifat mengikat bagi manusia. ${ }^{19}$ Seorang yang beragama tetap terikat dengan hukum-hukum dan aturan-aturan yang ditetapkan oleh agama.

Sidi Gazalba mengatakan bahwa yang dimaksud dengan kata relegere asal kata religi mengandung makna berhati-hati. Sikap berhati-hati ini disebabkan dalam religi terdapat norma-norma dan aturan yang ketat. Dalam religi ini orang Roma mempunyai anggapan bahwa manusia harus hati-hati terhadap Yang kudus dan Yang suci. ${ }^{20}$ Yang kudus dipercayai mempunyai sifat baik dan sekaligus mempunyai sifat jahat. ${ }^{21}$

Religi juga merupakan kecenderungan asli rohani manusia yang berhubungan dengan alam semesta, nilai yang meliputi segalanya, makna yang terakhir hakikat dari semua itu. Religi mencari makna dan nilai yang berbeda-beda sama sekali dari segala sesuatu yang dikenal. Karena itulah religi tidak berhubungan dengan yang kudus. Yang kudus itu belum tentu Tuhan atau dewa-dewa. Dengan demikian banyak sekali kepercayaan yang biasanya disebut religi, pada hal sebenarnya belum pantas disebut religi karena hubungan antara manusia dan yang kudus itu belum jelas. Religi-religi yang bersahaja dan Budhisma dalam bentuk awalnya misalnya menganggap Yang kudus itu bukan Tuhan atau dewadewa. Dalam religi betapa pun bentuk dan sifatnya selalu ada penghayatan yang berhubungan dengan Yang Kudus. ${ }^{22}$

Manusia mengakui adanya ketergantungan kepada Yang Mutlak atau Yang Kudus yang dihayati sebagai kontrol bagi manusia. Untuk mendapatkan pertolongan dari Yang Mutlak itu manusia secara bersamasama men-jalankan ajaran tertentu. Jadi religi adalah hubungan antara

${ }^{18}$ Hamzah Ya'qub, Filsafat Agama (Jakarta: Pedoman Ilmu Jaya, 1991), hlm. 3.

${ }^{19}$ Harun Nasution, Islam Ditinjau dari Berbagai Aspeknya, hlm. 10.

${ }^{20}$ Sidi Gazalba, Ilmu Filsafat dan Islam tentang Manusia dan Agama (Jakarta: Bulan Bintang, 1978), hlm. 100.

${ }^{21}$ Ibid.

${ }^{22}$ Ibid., hlm. 101. 
manusia dengan Yang Kudus. Dalam hal ini yang kudus itu terdiri atas ber-bagai kemungkinan, yaitu bisa berbentuk benda, tenaga, dan bisa pula berbentuk pribadi manusia. ${ }^{23}$

Selain itu, dalam bahasa Arab terdapat kata dîn yang menunjukkan pengertian agama. Kata dîn terdiri atas huruf dal, ya, dan nûn. Dari huruf-huruf ini bisa dibaca dengan dain yang berarti hutang ${ }^{24}$ dan dengan dîn yang berarti agama dan hari kiamat. Ketiga arti tersebut sama-sama menunjukkan adanya dua pihak yang berbeda. Pihak pertama berkedudukan lebih tinggi, berkuasa, ditakuti, dan disegani oleh pihak kedua. Dalam agama, Tuhan adalah sebagai pihak pertama yang lebih tinggi daripada manusia. Dalamhutang-piutang, yang menghutangi tentu lebih kaya dari yang berhutang. Demikian juga dalam masalah kiamat, Tuhan yang memiliki hari kiamat, sedangkan manusia adalah yang dimiliki dan manusia harus tunduk kepada si Pemilik. ${ }^{25}$

Dari akar kata itu, baik dîn maupun religi, dan agama, didefinisikan dalam berbagai ungkapan, antara lain pengakuan adanya hubungan manusia dengan kekuatan ghaib yang harus dipatuhi. E.B Tylor, sebagaimana dikutip Norman L. Geisler, mengatakan bahwa"agama adalah kepercayaan kepada wujud yang spiritual. Selanjutnya, dia membedakan antara yang suci dan yang agung. Tylor mengibaratkan, jika William Shakespeare memasuki ruangan, kita akan berdiri, tetapi jika Jesus memasuki ruangan, kita akan berlutut." ${ }^{26}$ Yang pertama adalah ungkapan kekaguman, sedangkan yang kedua adalah kepatuhan dan penyembahan.

${ }^{23}$ Oliver Leaman, Pengantar Filsafat Islam, alih bahasa M. amin Abdullah(Jakarta: Rajawali Pers, 1989), hlm. 183-188.

${ }^{24}$ Termasuk dalam arti hutang juga adalah janji. Dalam agama terdapat "janji" dan "ancaman". Ketika sudah tiba hari akhir, maka saat itulah hari pembalasan (pembayaran hutang) tiba. Mereka yang berperilaku baik selama di dunia akan mendapatkan balasan pahala dan mereka yang berperilaku buruk akan mendapatkan siksa. Zainal Arifin Abbas, Perkembangan terhadap Agama (Jakarta: Pustaka al-Husna, 1984), hlm. 72.

${ }^{25}$ Moh. Quraish Shihab, Mabkota Tuntunan Ilabi (Jakarta: Untagama, 1986), hlm. 35; Amsal Bakhtiar, Filsafat Agama, hlm. 10-11; Zainal Arifin Abbas, Perkembangan terbadap Agama, hlm. 72.

${ }^{26}$ Norman L. Geisler, Philosophy of Religion (Michigan: The Zondervan Corporation, 1974), hlm. 22. 
J.G. Frazer berpendapat bahwa agama adalah penyembahan kepada kekuatan yang lebih agung dari pada manusia, yang dianggap mengatur dan menguasai jalannya alam semesta. ${ }^{27}$ Menurut Mehdi Hai'ri Yazdi, agama adalah kepercayaan kepada yang Mutlak atau kehendak Mutlak sebagai kepedulian tertinggi. ${ }^{28}$

Durkheim berpendapat bahwa agama adalah alam gaib yang tidak dapat diketahui dan tidak dapat dipikirkan oleh akal manusia sendiri. Tegasnya, agama adalah suatu bagian dari ilmu pengetahuan yang tidak dapat diperoleh dengan tenaga pikiran saja. ${ }^{29}$

Pendapat Durkheim tersebut mengandung kebenaran, karena masalah yang gaib memang tidak dapat diterangkan lewat pendekatan rasional. Namun, penjelasan Durkheim belum lengkap karena agama tidak hanya berhubungan dengan masalah yang gaib saja, tetapi juga berkaitan dengan hakikat manusia sebagai makhluk jasmani dan rohani.

Dengan pendapat yang lebih profane, Auguste Comte mengatakan bahwaagama merupakan rekayasa manusia pada tingkat atau tahap primitf ketika manusia belum lagi mampu mengembangkan kapasitas rasionalnya, sedangkan sains merupakan pencapaian manusia paling akhir dan paling canggih, dengan fokus pada dunia material atau duniapositif. ${ }^{30}$

Menurut Saefuddin, agama merupakan kebutuhan paling esensial manusia yang bersifat universal. Karena itu, agama, menurutnya adalah kesadaran spiritual yang di dalamnya ada satu kenyataan di luar kenyataan yang tampak, yaitu bahwa manusia selalu mengharap belas kasih-Nya, bimbingan tangan-Nya, yang secara ontologism tidak bisa diingkari, walaupun oleh manusia yang paling komunis sekalipun. ${ }^{31}$

${ }^{27}$ Aslam Hady, Pengantar Filsafat Agama (Jakarta: Rajawali Pers, 1986), hlm. 6.

${ }^{28}$ Mehdi Hai' ri Yazdi, Ilm Hudhûrî (Bandung: Mizan, 1994), hlm. 169; Emile Durkheim, Sejarah Agama, alih bahasa Inyiak Ridwan Muzir(Yogyakarta: Ircisod, 2005), hlm. 399-406.

${ }^{29}$ Emile Durkheim, Sejarah Agama, hlm. 47-49; Zainal Arifin Abbas, Zainal Arifin Abbas, Perkembangan terhadap Agama, hlm. 52.

${ }^{30}$ George Ritzer dan Douglas J. Goodman, Teori Sosiologi; dari Teori Sosiologi Klasik sampai Perkembangan Mutakhir Teori Sosial Postmodern, alih bahasa Nurhadi (Bantul: Kreasi Wacana, 2010), hlm. 15-20; Juhaya S. Praja, Filsafat dan Metodologi Ilmu dalam Islam dan Penerapannya di Indoseia (Jakarta Selatan: Teraju, 2002), hlm. xvi.

${ }^{31}$ A.M. Saefuddin, dkk., Desekularisasi Pemikiran Landasan Islamisasi (Bandung: Mizan, 1987), hlm. 47. 
Menurut Sutan Takdir Alisjahbana, agama adalah suatu sistem kelakuan dan perhubungan manusia yang berpokok pada perhubungan manusia dengan rahasia kekuasaan dan kegaiban yang tiada terhingga luasnya, dalam dan mesranya di sekitarnya, dan dengan demikian memberi arti kepada hidupnya dan kepada alam semesta yang mengelilinginya. ${ }^{32}$

Parsudi Suparlan lebih mengkhususkan pengertian agama dalam konteks sosiologis. Menurutnya, agama adalah suatu sistem keyakinan yang dianut dan tindakan-tindakan yang diwujudkan oleh suatu kelompok atau masyarakat dalam menginterpretasikan dan memberi respon terhadap apa yang dirasakan dan diyakini sebagai yang gaib dan suci. Sebagai suatu sistem keyakinan, agama berbeda dari sistem-sistem keyakinan atau isme-isme lainnya, karena landasan keyakinan keagamaan adalah pada konsep suci yang dibedakan dari yang duniawi dengan yang gaib atau supranatural yang menjadi lawan dari hukum-hukum alamiah. ${ }^{33}$

Banyaknya terminology tentang agama di atas menunjukkan bahwa definisi agama secara lengkap belum tercapai dan terus berkembang seiring dengan penelitian terhadap agama yang terus dilakukan. Meski demikian, setidaknya terdapat beberapa unsur pokok yang dapat disimpulkan dari heterogenitas definisi agama tersebut, yaitu masalah yang gaib, adanya hubungan baik dengan kekuatan gaib tersebut, respon emosional dari manusia (rasa takut atau perasaan cinta), dan adanya halhal yang disucikan, seperti kitab suci dan tempat suci (ibadah).

\section{Filsafat Agama}

Setelah diketahui pengertian filsafat dan agama, maka definisi filsafat agama diperoleh dari gabungan keduanya, yaitu sebagai suatu usaha membahas tentang unsur-unsur pokok agama secara mendalam, menyeluruh, sistematis, logisdanbebas. ${ }^{34}$

Terlepas dari hal itu, Harun Nasution mengemukakan bahwa filsafat agama adalah berfikir tentang dasar-dasar agama menurut logika yang bebas. Pemikiran ini terbagi menjadi dua bentuk, ${ }^{35}$ yaitu: Pertama membahas

${ }^{32}$ Sutan Takdir Alisjahbana, Pemikiran Islam dalam Menghadapi Globalisasi (Jakarta: Dian Rakyat, 1992), hlm. 48.

${ }^{33}$ Roland Robeston, (ed.), Agama dalam Analisa dan Interpretasi Sosiologis (Jakarta: Rajawali Pers, 1993), hlm. vi.

${ }^{34}$ Amsal Bakhtiar, Filsafat Agama, hlm. 1-15.

${ }^{35}$ Karena begitu mendalamnya pembahasan tentang Tuhan terdapat dua 
dasar-dasar agama secara analitis dan kritis tanpa terikat kepada ajaran agama, dan tanpa tujuan untuk menyatakan kebenaran suatu agama. Kedua membahas dasar-dasar agama secara analitis dan kritis dengan maksud untuk menyatakan kebenaran suatu ajaran agama atau sekurang-kurangnya untuk menjelaskan bahwa apa yang diajarkan agama tidaklah mustahil dan tidak bertentangan dengan logika. ${ }^{36}$ Dasar-dasar agama yang dibahas antara lain pengiriman rasul, ketuhanan, roh manusia, keabadian hidup, hubungan manusia dengan Tuhan, soal kejahatan, dan hidup sesudah mati dan lain-lain. Oleh sebab itu pengertian filsafat agama adalah berfikir secara kritis dan analitis menurut aturan logika tentang agama secara mendalam sampai kepada setiap dasar-dasar agama itu. ${ }^{37}$

Karl Rahner menguraikan lebih jauh tentang filsafat agama. Menurutnya, filsafat agama adalah sebuah antropologi metafisik yang harus bersifat teologi dasar, yaitu manusia sebagai pribadi yang bebas yang pasti berhadapan dengan Tuhan yang mungkin mewahyukan diri. Oleh karena itu, filsafat agama adalah keterbukaan yang siap sedia dan kesediaan yang terbuka bagi teologi. Filsafat agama tidak dapat memaksa teologi dan tidak dapat menentukan hukumnya, melainkan seorang filofof agama melaksanakan apa yang harus dilaksanakan oleh seorang makhluk yang dapat mendengar jika Logos Tuhan datang ke dunia. Rahner kemudian mempertegas antara wilayah teologi dan filsafat. Filsafat agama tidak dapat menjangkau fakta wahyu, hanya dengan teologilah fakta wahyu itu dapat ditangkap dan dimengerti. ${ }^{38}$

kemungkinan yang akan terjadi. Dengan mempelajari agama bisa seseorang berubah keyakinan. Ada orang yang membahas persoalan kepercayaan dalam agama itu menambah keyakinannya terhadap Tuhan. Ada orang yang membahas persoalan kepercayaan tentang Tuhan, tetapi karena ia tidak mendapatkan kepuasan dalam penemuannya sehingga orang itu berpaling dari keyakinannya semula. Jika seorang pada mulanya percaya kepada Tuhan, tetapi setelah membahas eksistensi Tuhan ia bisa menjadi tidak percaya kepada Tuhan. Sebaliknya, seorang yang ateis, yang kemungkinan dalam hidupnya mengalami kekosongan dan kegersangan jiwa setelah berfikir tentang pengalaman orang yang beragama bisa pula menjadi penganut agama yang kuat. Harry Hammersma, Tokoh-Tokob Filsafat Barat Moderen (Jakarta: Gramedia, 1990), hlm. 79 dan 81.

${ }^{36}$ Harun Nasution, Islam Ditinjau, hlm. 11.

${ }^{37}$ H. A. Mustofa, Filsafat Islam, hlm. 20-25.

${ }^{38}$ Nico Syukur Dister OFM, Filsafat Agama Kristiani (Jakarta: BPK Gunung Mulia, 1985), hlm. 90. 
Lebih lanjut, Rahner menambahkan bahwa filsafat agama harus menunjukkan secara filosofis di manakah dalam diri manusia timbul agama, apa nilainya agama semacam itu, dan apakah Tuhan ada atau tidak. Filsafat agama yang menanyakan hakikat agama, menurut Rahner, bagaimanapun juga harus sampai kepada pengenalan Allah yang transenden, absolut, dan personal. ${ }^{39}$

Menurut C.D.Mulder, filsafat agama merupakan bagian dari filsafat ketuhanan. Filsafat ketuhanan termasuk filsafat sistematis yang mempelajari kosmos, manusia, dan Tuhan. ${ }^{40}$

Geddes Mac Gregor menekankan pembahasan filsafat agama harus dibedakan antara hal yang menarik hati dalam agama dan berpikir tentang agama. Yang pertama adalah aktifitas hati, dan yang kedua adalah aktifitas akal. Selanjutnya Gregor mengatakan bahwa pendekatan intelektual terhadap agama tidak akan memuaskan hati, sementara pendekatan intelektual hanya akan memuaskan akal. ${ }^{41}$

Dalam definisi yang dikemukakan Gregor terlihat suatu pemilahan antara kegiatan hati dan akal. Daya akal menurutnya sebagai penjelas dalam menganalisis ajaran agama, dan daya hati berfungsi untuk memuaskan perasaan penganut agama. ${ }^{42}$

\section{E. Filsafat dan Agama; Sebuah Kajian Kompromistis}

Apabila dikaji hubungan antara filsafat dan agama dalam sejarah kadang-kadang dekat dan baik, dan kadang-kadang jauh dan buruk. Ada kalanya para agamawan merintis perkembangan filsafat. Ada kalanya pula orang beragama merasa terancam oleh pemikiran para filosof yang kritis

\section{${ }^{39}$ Ibid.}

${ }^{40}$ AslamHady, PengantarFilsafat Agama, hlm.8; AmsalBakhtiar, Filsafat Agama, hlm. 15-16.

${ }^{41}$ Geddes Mac Gregor, Introduction to Religious Philosophy (London: Macmillan LTD, 1960), hlm. 11.

${ }^{42}$ Menurut Murtadha Muthahhari, pandangan para filosof masa lalu terhadap filsafat mempunyai dua arti. Pertama, pengertian umum dari pengetahuan rasional, meliputi semua sains kecuali ilmu yang diperoleh melalui pewahyuan. Kedua, pengertian lain yang agak jarang, yaitu teologi dan filsafat. Penggunaan logika secara intuitif biasanya dibayang-bayangi oleh pengaruh wahyu. Lihat Murtadha Muthahhari, Tema-Tema Penting Filsafat Islam (Bandung: Yayasan Muthahhari, 1993), hlm.14-19. 
dan tajam. Para filosof sendiri kadang-kadang memberi kesan sombong, sok tahu, meremehkan wahyu dan iman sederhana umat. ${ }^{43}$

Kadang-kadang juga terjadi bentrokan, di mana filosof menjadi korban kepicikan dan kemunafikan orang-orang yang mengatas namakan agama. Socrates dipaksa minum racun atas tuduhan atheisme padahal ia justru berusaha mengantar kaum muda kota Athena kepada penghayatan keagamaan yang lebih mendalam. ${ }^{44}$ Filsafat Ibn Rusyd dianggap menyeleweng dari ajaran-ajaran Islam, ia ditangkap, diasingkan dan meninggal dalam pembuangan. ${ }^{45}$ Abelard (1079-1142) yang mencoba mendamaikan iman dan pengetahuan mengalami pelbagai penganiayaan. Thomas Aquinas (1225-1274), filosof dan teolog terbesar Abad Pertengahan, dituduh kafir karena memakai pendekatan Aristoteles (yang diterima para filosof Abad Pertengahan dari Ibn Sina dan Ibn Rusyd). Giordano Bruno dibakar pada tahun 1600 di tengah kota Roma. Sedangkan di zaman moderen tidak jarang seluruh pemikiran filsafat sejak dari Auflklarung dikutuk sebagai anti agama dan atheis. ${ }^{46}$

Pada akhir abad ke-20, situasi mulai jauh berubah. Baik dari pihak filsafat maupun dari pihak agama. Filsafat makin menyadari bahwa pertanyaan-pertanyaan manusia paling dasar tentang asal-usul yang sebenarnya, tentang makna kebahagiaan, tentang jalan kebahagiaan, tentang tanggungjawab dasar manusia, tentang makna kehidupan, tentang apakah hidup ini berdasarkan sebuah harapan fundamental atau sebenarnya tanpa arti paling-paling dapat dirumuskan serta dibersihkan dari kerancuan-kerancuan, tetapi tidak dapat dijawab. Keterbukaan filsafat, termasuk banyak filosof Marxis, terhadap agama belum pernah

${ }^{43}$ Menurut al-Ghazali, sebagaimana dikutip Muhammad Yasir Nasution, ketika ada masalah yang tidak ditemukan dalam al-Qur'an dan Hadits, akal dengan sendirinya berperan sebagai alat interpretasi terhadap wahyu dalam penyelesaian persoalan-persoalan. Lihat Muhammad Yasir Nasution, Manusia Menurut Al-Ghazali (Jakarta: PT. Raja Grafindo Persada, 1999), hlm. 30-31.

${ }^{44}$ Bertrand Russel, Sejarah Filsafat Barat dan Kaitannya dengan Kondisi SosioPolitik dari Zaman Kuno hingga Sekarang, alih bahasa Sigit Jatmiko, dkk. (Yogyakarta: Pustaka Pelajar, 2007), hlm. 111-123.

${ }^{45}$ Ibn Rusyd, Tahâfut at-Tahâfut; Sanggahan terbadap Tahâfut al-Falâsifa, alih bahasa Khalifurrahman Fath (Yogyakarta: Pustaka Pelajar, 2004), hlm.3-4; H.A. Mustofa, Filsafat Islam, hlm. 284-289.

${ }^{46}$ Ibid., hlm. 27-37. 
sebesar dewasa ini. ${ }^{47}$

Sebaliknya agama, meskipun dengan lambat, mulai memahami bahwa sekularisasi yang dirasakan sebagai ancaman malah membuka kesempatan juga. Kalau sekularisasi berarti bahwa apa yang duniawi dibersihkan dari segala kabut adiduniawi, jadi bahwa dunia adalah dunia dan Allah adalah Allah, dan dua-duanya tidak tercampur, maka sekularisasi itu sebenarnya hanya menegaskan apa yang selalu menjadi keyakinan dasar monotheisme. Sekularisasi lantas hanya berarti bahwa agama tidak lagi dapat mengandalkan kekuasaan duniawi dalam membawa pesannya, dan hal itu justru membantu membersihkan agama dari kecurigaan bahwa agama sebenarnya hanyalah suatu legitimasi bagi sekelompok orang untuk mencari kekuasaan di dunia. Agama dibebaskan kepada hakekatnya yang rohani dan adiduniawi (agama, baru menjadi saksi kekuasaan Allah yang adiduniawi apabila dalam mengamalkan tugasnya tidak memakai saranasarana kekuasaan, paksaan dan tekanan duniawi. ${ }^{48}$

Penyatuan agama dan filsafat sudah tidak dapat terelakkan lagi. Hal itu dapat terlihat dalam, pertama,salah satu masalah yang dihadapi oleh setiap agama wahyu adalah masalah interpretasi. Maksudnya, teks wahyu yang merupakan Firman Allah selalu dan dengan sendirinya terumus dalam bahasa dari dunia. Akan tetapi segenap makna dan arti bahasa manusia tidak pernah seratus persen pasti. Itulah sebabnya kita begitu sering mengalami apa yang disebut salah paham. Hal itu juga berlaku bagi bahasa wahana wahyu. Hampir pada setiap kalimat ada kemungkinan salah tafsir. ${ }^{49}$ Oleh karena itu para penganut agama yang sama pun sering masih cukup berbeda dalam pahamnya tentang isi dan arti wahyu. Dengan kata lain, kita tidak pernah seratus persen merasa pasti bahwa pengertian kita tentang maksud Allah yang terungkap dalam teks wahyu memang tepat, memang itulah maksud Allah. ${ }^{50}$

Oleh sebab itu, setiap agama wahyu mempunyai cara untuk

${ }^{47}$ Bertrand Russel, Sejarah Filsafat Barat, hlm. 643-645.

${ }^{48}$ Seyyed Hossen Nasr dan Oliver Leaman, Ensiklopedi Tematis Filsafat Islam, hlm. 36-46; Sted Muhammad Al-Naquib Al-Attas, Islam dan Sekularisme, hlm. 18-26.

${ }^{49}$ Harvey Cox, The Secular City (New York: tp., 1965), hlm. 2.

${ }^{50}$ Musa Asy'arie, Filsafat Islam, Sunnah Nabi dalam Berpikir(Yogyakarta: LESFI, 2002), hlm. 31-37; Muhammad Yasir Nasution, Manusia Menurut Al-Ghazali, hlm. 135-140. 
menangani masalah itu. Agama Islam, misalnya, mengenai ijmâ' dan qiyâs. Nah, dalam usaha manusia seperti itu, untuk memahami wahyu Allah secara tepat, untuk mencapai kata sepakat tentang arti salah satu bagian wahyu, filsafat dapat saja membantu. Karena jelas bahwa jawaban atas pertanyaan itu harus diberikan dengan memakai nalar (pertanyaan tentang arti wahyu tidak dapat dipecahkan dengan mencari jawabannya dalam wahyu saja, karena dengan demikian pertanyaan yang sama akan muncul kembali, dan seterusnya). Karena filsafat adalah seni pemakaian nalar secara tepat dan bertanggungjawab, filsafat dapat membantu agama dalam memastikan arti wahyunya. ${ }^{51}$

Kedua, secara spesifik, filsafat selalu dan sudah memberikan pelayanan kepada ilmu yang mencoba mensistematisasikan, membetulkan dan memastikan ajaran agama yang berdasarkan wahyu, yaitu ilmu teologi. Maka secara tradisional-dengan sangat tidak disenangi oleh para filosoffilsafat disebut ancilla theologiae (abdi teologi). Teologi dengan sendirinya memerlukan paham-paham dan metode-metode tertentu, dan pahampaham serta metode-metode itu dengan sendirinya diambil dari filsafat. Misalnya, masalah penentuan Allah dan kebebasan manusia (masalah kehendak bebas) hanya dapat dibahas dengan memakai cara berpikir filsafat. Hal yang sama juga berlaku dalam masalah "theodicea", pertanyaan tentang bagaimana Allah yang sekaligus Mahabaik dan Mahakuasa, dapat membiarkan penderitaan dan dosa berlangsung (padahal ia tentu dapat mencegahnya). Begitu pula Christologi (teologi kristiani tentang Yesus Kristus) mempergunakan paham-paham filsafat Yunani dalam usahanya mempersatukan kepercayaan pada hakekat nahi Yesus Kristus dengan kepercayaan bahwa Allah hanyalah satu. ${ }^{52}$

Ketiga, filsafat dapat membantu agama dalam menghadapi masalahmasalah baru, artinya masalah-masalah yang pada waktu wahyu diturunkan belum ada dan tidak dibicarakan secara langsung dalam wahyu. Itu terutama relevan dalam bidang moralitas. Misalnya masalah

${ }^{51}$ Seyyed Hossen Nasr dan Oliver Leaman, Ensiklopedi Tematis Filsafat Islam, hlm. 36-46; H. A. Mustofa, Filsafat Islam, hlm 18-20; Musa Asy'arie, Filsafat Islam, hlm. 30-37.

${ }^{52}$ Seyyed Hossen Nasr dan Oliver Leaman, Ensiklopedi Tematis Filsafat Islam, hlm. 36-46; H. A. Mustofa, Filsafat Islam, hlm 18-20; Musa Asy'arie, Filsafat Islam, hlm. 30-37. 
bayi tabung atau pencangkokan ginjal. Bagaimana orang mengambil sikap terhadap dua kemungkinan itu: Boleh atau tidak? Bagaimana dalam hal ini ia mendasarkan diri pada agamanya, padahal dalam Kitab Suci agamanya, dua masalah itu tak pernah dibahas? Jawabannya hanya dapat ditemukan dengan cara menerapkan prinsip-prinsip etika yang termuat dalam konteks lain dalam Kitab Suci pada masalah baru itu. Nah, dalam proses itu diperlukan pertimbangan filsafat moral. ${ }^{53}$

Filsafat juga dapat membantu merumuskan pertanyaan-pertanyaan kritis yang menggugah agama, dengan mengacu pada hasil ilmu pengetahuan dan ideologi-ideologi masa kita, misalnya pada ajaran evolusi atau pada feminisme. ${ }^{54}$

Pelayanan keempat yang dapat diberikan oleh filsafat kepada agama diberikan melalui fungsi kritisnya. Salah satu tugas filsafat adalah kritik ideologi. Maksudnya adalah sebagai berikut. Masyarakat terutama masyarakat pasca tradisional, berada di bawah semburan segala macam pandangan, kepercayaan, agama, aliran, ideologi, dan keyakinan. Semua pandangan itu memiliki satu kesamaan: Mereka mengatakan kepada masyarakat bagaimana ia harus hidup, bersikap dan bertindak. Filsafat menganalisa claim-claim ideologi itu secara kritis, mempertanyakan dasarnya, memperlihatkan implikasinya, membuka kedok kepentingan yang barangkali ada di belakangnya. ${ }^{55}$

Kritik ideologi itu dibutuhkan agama dalam dua arah. Pertama terhadap pandangan-pandangan saingan, terutama pandanganpandangan yang mau merusak sikap jujur, takwa dan bertanggungjawab. Fisafat tidak sekedar mengutuk apa yang tidak sesuai dengan pandangan kita sendiri, melainkan mempergunakan argumentasi rasional. Agama sebaiknya menghadapi ideologi-ideologi saingan tidak secara dogmatis belaka, jadi hanya karena berpendapat lain, melainkan berdasarkan

${ }^{53}$ Muhammad Yasir Nasution, ManusiaMenurut Al-Ghazali, hlm. 25-30; Seyyed Hossen Nasr dan Oliver Leaman, Ensiklopedi Tematis Filsafat Islam, hlm. 36-46; H. A. Mustofa, Filsafat Islam, hlm 18-20; Musa Asy'arie, Filsafat Islam, hlm. 30-37.

${ }^{54}$ Amsal Bakhtiar, Filsafat Agama, hlm. 1-16; SeyyedHossen Nasr dan Oliver Leaman, Ensiklopedi Tematis Filsafat Islam, hlm. 36-46; H. A. Mustofa, Filsafat Islam, hlm 18-20; Musa Asy'arie, Filsafat Islam, hlm. 30-37.

${ }^{55}$ Harun Nasution, Islam Ditinjau dari Berbagai Aspeknya, hlm. 10; Amsal Bakhtiar, Filsafat Agama, hlm. 1-16. 
argumentasi yang obyektif dan juga dapat dimengerti orang luar. ${ }^{56}$

Arah kedua menyangkut agamanya sendiri. Filsafat dapat mempertanyakan, apakah sesuatu yang oleh penganut agama dikatakan sebagai termuat dalam wahyu Allah, memang termasuk wahyu itu. Jadi, filsafat dapat menjadi alat untuk membebaskan ajaran agama dari unsurunsur ideologis yang menuntut sesuatu yang sebenarnya tidak termuat dalam wahyu, melainkan hanya berdasarkan sebuah interpretasi subyektif. Maka filsafat membantu pembaharuan agama. Berhadapan dengan tantangan-tantangan zaman, agama tidak sekedar menyesuaikan dirinya, melainkan menggali jawabannya dengan berpaling kembali kepada apa yang sebenarnya diwahyukan oleh Allah. ${ }^{57}$

Mengenai dikotomi agama dan filsafat serta hubungan antara keduanya para pemikir terpecah dalam tiga kelompok: kelompok pertama, berpandangan bahwa antara keduanya terdapat hubungan keharmonisan dan tidak ada pertentangan sama sekali. Kelompok kedua, memandang bahwa filsafat itu bertolak belakang dengan agama dan tidak ada kesesuaiannya sama sekali. Kelompok ketiga, yang cenderung moderat ini, substansi gagasannya adalah bahwa pada sebagian perkara dan persoalan terdapat keharmonisan antara agama dan filsafat dimana kaidah-kaidah filsafat dapat diaplikasikan untuk memahami, menafsirkan dan menakwilkan ajaran agama. ${ }^{58}$

Anselm dalam risalah filsafatnya yang berjudul "Proslogion" mengungkapkan kalimat yang menarik berbunyi: Saya beriman supaya bisa mengetabui. Apabila kalimat ini kita balik akan menjadi: jika saya tidak beriman, maka saya tak dapat mengetabui. Tak dapat disangkal bahwa Anselm meyakini bahwa keimanan agama adalah sumber motivasi dan pemicu yang kuat untuk mendorong seseorang melakukan penelitian dan pengkajian yang mendalam terhadap ajaran-ajaran doktrinal agama, lebih jauh, keimanan sebagai sumber inspirasi lahirnya berbagai ilmu dan pengetahuan. Kesempurnaan iman dan kedalaman pengahayatan

${ }^{56}$ Ibid.

${ }^{57}$ Sebenarnya filsafat Islam itu juga berakar dari al-Qur'an dan Hadits, seperti disiplin ilmu lainnya yang berlabel "Islam." Lihat Seyyed Hossein Nasr dan Oliver Leaman (ed.), Ensiklopedi TematisFilsafat Islam (Buku Pertama), (Bandung: Mizan, 2003), hlm. 36-38

${ }^{58}$ H. A. Mustofa, Filsafat Islam, hlm 14-20; Musa Asy'arie, Filsafat Islam, hlm. 30-37; Amsal Bakhtiar, Filsafat Agama, hlm. 1-16. 
keagamaan seseorang adalah berbanding lurus dengan pemahaman rasionalnya terhadap ajaran-ajaran agama, semakin dalam dan tinggi pemahaman rasional maka semakin sempurna keimanan dan semakin kuat apresiasi terhadap ajaran-ajaran agama. Manusia membutuhkan rasionalisasi dalam semua aspek kehidupannya, termasuk dalam doktrindoktrin keimanannya, karena akal dan rasio adalah hakikat dan substansi manusia, keduanya mustahil dapat dipisahkan dari wujud manusia, bahkan manusia menjadi manusia karena akal dan rasio. Tolak ukur kesempurnaan manusia adalah akal dan pemahaman rasional. Akal merupakan hakikat manusia dan karenanya agama diturunkan kepada umat manusia untuk menyempurnakan hakikatnya. Penerimaan, kepasrahan dan ketaatan mutlak kepada ajaran suci agama sangat berbanding lurus dengan rasionalisasi substansi dan esensi ajaran-ajaran agama. ${ }^{59}$

Substansi dari semua ajaran agama adalah keyakinan dan kepercayaan terhadap eksistensi Tuhan, sementara eksistensi Tuhan hanya dapat dibuktikan secara logis dengan menggunakan kaidah-kaidah akal-pikiran (baca: kaidah filsafat) dan bukan dengan perantaraan ajaran agama itu sendiri. Walaupun akal dan agama keduanya merupakan ciptaan Tuhan, tapi karena wujud akal secara internal terdapat pada semua manusia dan tidak seorang pun mengingkarinya, sementara keberadaan ajaran-ajaran agama yang bersifat eksternal itu tidak diterima oleh semua manusia.

Dengan demikian, hanya akallah yang dapat kita jadikan argumen dan dalil atas eksistensi Tuhan dan bukan ajaran agama. Seseorang yang belum meyakini wujud Tuhan, lantas apa arti agama baginya. Kita mengasumsikan bahwa ajaran agama yang bersifat doktrinal itu adalah ciptaan Tuhan, sementara belum terbukti eksistensi Pencipta dan pengenalan sifat-sifat sempurna-Nya, dengan demikian adalah sangat mungkin yang diasumsikan sebagai "ciptaan Tuhan" sesungguhnya adalah "ciptaan makhluk lain" dan makhluk ini lebih sempurna dari manusia (sebagaimana manusia lebih sempurna dari hewan dan makhluk-makhluk alam lainnya). Lantas bagaimana kita dapat meyakini bahwa seluruh ajaran agama itu adalah berasal dari Tuhan. Walaupun kita menerima eksistensi Tuhan dengan keimanan dan membenarkan bahwa semua ajaran agama berasal dari-Nya, tapi bagaimana kita dapat menjawab soal bahwa

${ }^{59}$ Abul Qasim Baihaqi, Durrah al-Akbbâr wa Lum'ah al-Anwâr (Mesir: Dar al-Kitab al-Sa'adah, tt.), hlm. 28. 
apakah Tuhan masih hidup? Kenapa sekarang ini tidak diutus lagi Nabi dan Rasul yang membawa agama baru? Dan masih banyak lagi soal-soal seperti itu yang hanya bisa diselesaikan dengan kaidah akal-pikiran. Berdasarkan perspektif ini, akal merupakan syarat mendasar dan mutlak atas keberagamaan seseorang, dan inilah rahasia ungkapan yang berbunyi: Tidak ada agama bagi yang tidak berakal. ${ }^{60}$

Amiri memandang bahwa akal secara esensial mengikuti dan taat kepada perintah-perintah Tuhan. Di bagian lain dari kitab itu, akal dikategorikan sebagai bujjah dan dalil Tuhan, ia menyatakan bahwa derajat akal apabila dibandingkan dengan jiwa sama seperti daya penglihatan apabila dihubungkan dengan mata. 'Amiri, dalam kitab as-sa'âdah wa alisâd, jug menyinggung hubungan akal, jiwa dan alam materi, ia berkata, "Jiwa mengambil manfaat dari akal dan menyalurkan manfaat ke alam materi. Akal adalah kemuliaan dan kehormatan jiwa dan jiwa adalah pelayan akal. Ketika jiwa melayani akal maka pada jiwa akan nampak kesucian dan cahaya dan ketika ia meninggalkan akal maka akan nampak kegelapan dan kekotoran. Dengan demikian, kebodohan akan muncul dan berefek pada kehancuran dan kemaksiatan." ${ }^{11}$

Amiri beranggapan bahwa jiwa yang berakal mempunyai kelayakan untuk menjadi khalifah Tuhan. Menurutnya, seseorang yang memiliki jiwa yang dicahayai oleh akal layak menjadi khalifah Tuhan yang mengatur, mengelolah dan membangun alam ini, dan di alam non-materi menempati kedudukan yang mulia dan tinggi. Jiwa ini, dari sisi badan berhubungan dengan alam rendah (materi) dan dari dimensi akal berkaitan dengan alam tinggi. Dengan ibarat lain, khalifah Tuhan adalah substansi wujudnya memiliki kedudukan ruhani dan spiritual tertinggi dan juga berhubungan dengan derajat jasmani terendah, maujud ini tidak lain merupakan sesuatu yang menghubungkan dan menggabungkan dua alam. ${ }^{62}$

${ }^{60}$ Ibid., hlm. 29-31; Rob Fisher, "Pendekatan Filosofis," dalam Peter Connolly (ed.), Aneka Pendekatan Studi Agama (Yogyakarta: LKiS, 2002), hlm. 149-156.

${ }^{61}$ Abul Hasan 'Amiri, al-Sa'âdah wa al-Is'âd (Beirut: tp., tt.) hlm. 180

${ }^{62}$ Ibid.; Peter Connolly, Aneka Pendekatan Studi Agama (Yogyakarta: LKiS, 2002), hlm. 1-11. 


\section{F. Kesimpulan}

Agama dan filsafat sama sekali tidak dapat dipertentangkan, bahkan, keduanya justru dapat saling melengkapi. Filsafat dapat digunakan untuk memahami sisi "tersembunyi" agama, dan agama dapat berfungsi sebagai pengendali rasionalitas.

Jika filsafat membincangkan tentang eksistensi-eksistensi di alam dan tujuan akhir perjalanan adalah segala yang maujûd, maka agama dapat menyodorkan asumsi-asumsi penting sebagai subyek penelitian dan pengkajian filsafat. 


\section{Daftar Pustaka}

Abbas, Zainal Arifin, Perkembangan terhadap Agama, Jakarta: Pustaka al-Husna, 1984.

Alisjahbana, Sutan Takdir, Pemikiran Islam dalam Menghadapi Globalisasi, Jakarta: Dian Rakyat, 1992.

Amiri, Abul Hasan, al-Sa'âdah wa al-Is'âd, Beirut: tp., tt..

Asy'arie, Musa, Filsafat Islam, SunnabNabi dalam Berpikir, Yogyakarta: LESFI, 2002.

Attas Al-, Syed Muhammad Al-Naquib, Islam dan Sekularisme, alih bahasa Karsidjo Djojosuwarno, Bandung: Penerbit Pustaka, 1981.

Bakhtiar, Amsal, Filsafat Agama I, Jakarta: Logos Wacana Ilmu, 1997.

Baihaqi, Abul Qasim, Durrah al-Akbbârwa Lum'ah al-Anwâr, Mesir: Dar al-Kitab al-Sa'adah, tt.

Beekman, Gerard, Filsafat para Filosof Berfilsafat, diterjemahkan oleh R. A. Rifai dari Filosofie, Filosofen, dan Filosoferen, Jakarta: Erlangga, 1984.

Connolly, Peter, Aneka Pendekatan Studi Agama, Yogyakarta: LKiS, 2002.

Cox, Harvey, The Secular City, New York: tp., 1965.

Dardiri, H.A., Humaniora, Filsafat dan Logika, Jakarta: Rajawali Press, 1986.

Durkheim, Emile, Sejarah Agama, alih bahasa Inyiak Ridwan Muzir, Yogyakarta: Ircisod, 2005.

Fisher, Rob, "Pendekatan Filosofis," dalam Peter Connolly (ed.), Aneka Pendekatan Studi Agama, Yogyakarta: LKiS, 2002.

Gazalba, Sidi, Ilmu Filsafat dan Islam tentang Manusia dan Agama, Jakarta: Bulan Bintang, 1978.

Geisler, Norman L., Philosophy of Religion, Michigan: The Zondervan Corporation, 1974.

Gregor, Geddes Mac, Introduction to Religious Philosophy, London: Macmillan LTD, 1960. 
Hammersma, Harry, Tokoh-Tokob Filsafat Barat Moderen, Jakarta: Gramedia, 1990.

Kattsoff, Louis O, Pengantar Filsafat, terjemahan dari Element of Philosophy, oleh Soejono Soemargono, Yogyakarta: Tiara Wacana, 1992.

Leaman, Oliver, Pengantar Filsafat Islam, alih bahasa M. amin Abdullah, Jakarta: Rajawali Pers, 1989.

Minhaji, Akh.,Strategies for Social Research: The Methodological Imagination in Islamic Studies, Yogyakarta: Suka-Press, 2009.

Mustofa, H. A., Filsafat Islam untukFakultasTarbiyah, Syari'ah, Dakwah, Adab, danUshuluddin, Komponen MKDK, Bandung: PustakaSetia, 2004.

Muthahhari, Murtadha, Tema-Tema Penting Filsafat Islam, Bandung: Yayasan Muthahhari, 1993.

Nasution, Harun, Islam Ditinjau dari Berbagai Aspeknya, cet. ke-1, Jakarta: Universitas Indonesia Press, 1979.

Nasution, Muhammad Yasir, Manusia Menurut Al-Ghazali, Jakarta: PT. Raja Grafindo Persada, 1999.

OFM, Nico Syukur Dister, Filsafat Agama Kristiani, Jakarta: BPK Gunung Mulia, 1985.

Praja, Juhaya S., Filsafat dan Metodologi Ilmu dalam Islam dan Penerapannya di Indoseia, Jakarta Selatan: Teraju, 2002.

Rasyidi, Filsafat Agama, Jakarta: Bulan Bintang, 1965.

Ritzer, George dan Douglas J. Goodman, Teori Sosiologi; dari Teori Sosiologi Klasik sampai Perkembangan Mutakbir Teori Sosial Postmodern, alih bahasa Nurhadi, Bantul: Kreasi Wacana, 2010.

Robeston, Roland, (ed.), Agama dalam Analisa dan Interpretasi Sosiologis, Jakarta: Rajawali Pers, 1993.

Russel, Bertrand, Sejarab Filsafat Barat dan Kaitannya dengan Kondisi SosioPolitik dari Zaman Kuno hingga Sekarang, alih bahasa Sigit Jatmiko, dkk., Yogyakarta: Pustaka Pelajar, 2007. 
Rusyd, Ibn, Tahâfut at-Tahâfut; Sanggahan terbadap Tahâfut al-Falâsifa, alih bahasa Khalifurrahman Fath, Yogyakarta: Pustaka Pelajar, 2004.

Saefuddin, A.M., dkk., Desekularisasi Pemikiran Landasan Islamisasi, Bandung: Mizan, 1987.

Shihab, Moh. Quraish, Mabkota Tuntunan Ilabi, Jakarta: Untagama, 1986.

Subhi, Ahmad Mahmud, Dirâsât Falsafiyyah fi 'Ilm al-Kalâm, ttp.: Dâr al-Kutub al-Jami'iyyah, 1969.

Suriasumantri, Jujun S., Filsafat Ilmu, Sebuah Pengantar Populer, Jakarta: Sinar Harapan, 1995.

Tafsir, Ahmad, Filsafat Umum, Akal dan Hati sejak Thales sampai James, Bandung: Rosdakarya, 1994.

Thohir, Umar Faruq, "Keseimbangan Doa dan Usaha; Paradigma Baru Efektifitas Manajemen Kehidupan," dalam Lukas Awi Tristanto (ed.), Inspirasi: Memaknai kembali Arti Devosi, Semarang: Suryandaru Utama, 2011.

Ya’qub, Hamzah, Filsafat Agama, Jakarta: Pedoman Ilmu Jaya, 1991.

Yazdi, Mehdi Hai'ri, Ilm Hudhôr̂̂, Bandung: Mizan, 1994. 